\title{
Overview of cephalopod fisheries in Chilean waters
}

Francisco Rocha ${ }^{a}$, Marco A. Vega ${ }^{b}$

a Laboratorio de Ecología y Biología Marina, ECOBIOMAR, Instituto de Investigaciones Marinas (CSIC), C/Eduardo Cabello 6, 36208 Vigo, Spain

${ }^{\mathrm{b}}$ Laboratorio de Hidrobiología, Facultad de Ciencias, Universidad de Chile, Casilla 653, Santiago, Chile

\begin{abstract}
This paper describes the history of cephalopod fisheries in Chile over the past 40 years. Continuous monitoring of three species was undertaken between 1978 and 1999: Loligo gahi, Dosidicus gigas and Octopus mimus. Total cephalopod catches increased from 69 tonnes in 1978 (0.13\% total mollusc catch) to 3503 tonnes in $1996(3.64 \%)$. A maximum haul of 15,169 tonnes was taken in 1992 (11.27\% total mollusc catch). Small-scale fisheries accounted for the majority of cephalopod captures and industrial catches were rare. L. gahi is caught year-round mainly in the south of Chile, with maximum catches in summer and autumn. Catches of D. gigas are also year-round, mainly concentrated in central Chile. O. mimus has been fished since 1978, although recorded as Octopus vulgaris until the 1990s. The O. mimus fishery is located on the north coast of Chile, and catches are made for the most of the year. Octopus has been landed in the south of Chile since 1991, and is considered as O. mimus in capture statistics despite the fact that several species are represented, including Enteroctopus megalocyathus
\end{abstract}

Keywords: Loligo gahi; Dosidicus gigas; Octopus mimus; Enteroctopus megalocyathus; Fisheries; Chile

\section{Introduction}

Cephalopods are an important alternative to traditional fish stocks where catches of the latter have declined through over-exploitation (Caddy and Rodhouse, 1998). These faster-growing species may be better adapted to heavy fishing pressure than slowergrowing fish species (Caddy and Rodhouse 1998; Caddy, 1999). Over the last 50 years, 
cephalopod production has shown a remarkable increase from 0.6 million tonnes in 1950 to 3.5 million tonnes in 1999 (FAO Database; Josupeit, 2000). Although the exploitation level of some neritic cephalopod species in different parts of the world is high, there are some potential resources that are practically unexploited (Caddy and Rodhouse, 1998; Josupeit, 2000).

The Chilean fishing fleet is an important sector of the economy. It is composed of some 450 industrial and a further 13,000 small-scale vessels catching 7-8.5 million tonnes per year. During the 1990s, Chilean catches comprised fishes (93\%), molluscs (2\%), algae $(3.4 \%)$, crustaceans $(0.6 \%)$ and other taxa $(1 \%)$. Exploitation of cephalopods in Chilean waters is low ( $2-5 \%$ of molluscs, $0.05-0.2 \%$ of total catch during the $1990 \mathrm{~s}$ ) (SERNAPESCA database). Aside from the small-scale octopus fishery of northern Chile, these molluscs are not considered target species (Villaroel et al., 2001). In addition, biological and fishery information on cephalopods in Chile is scarce (Rocha, 1997) and the importance of cephalopods within the national market is minimal, although on the increase.

Cephalopod fisheries in Chile are focused on three species, Loligo gahi, Dosidicus gigas and Octopus mimus. L. gahi, the Patagonian squid, is a species caught by trawlers and small-scale operators, and is rarely sold in local markets. The biology and ecology of L. gahi are practically unknown in Chilean waters (Arancibia and Robotham, 1984) despite being one of the target species of the international cephalopod fishery in the South Atlantic (Hatfield and Des Clers, 1998). The Jumbo Flying Squid, D. gigas, is an important cephalopod in the eastern Pacific. Distributed from the Gulf of California $\left(45^{\circ} \mathrm{N}\right)$ to the south of Chile $\left(45^{\circ} \mathrm{S}\right)$ (Nigmatullin et al., 2001), it is occasionally caught in Chilean waters. High concentrations of this species are found between Baja California and northern Chile, especially in the waters of the Peruvian Current (Kuroiwa, 1998; Nigmatullin et al., 2001). D. gigas is taken in a pelagic fishery off Peru, where high population densities have been recorded (Kuroiwa, 1998; Yamashiro et al., 1998; Taipe et al., 2001).

Finally, small-scale scuba fisheries in northern Chile and Peru catch Changos Octopus, O. mimus. Although there have been some studies on this fishery (Cortez, 1995; Defeo and Castilla, 1998), little is known about its biology, distribution and abundance. 
There have been no studies to date on the development and future of Chilean cephalopod fisheries. This paper describes the history of cephalopod fisheries in Chile using landing data collected over the last 40 years, with particular emphasis on the period 1978-1999 (when records are most complete).

\section{Material and methods}

Data on cephalopod captures in Chilean waters corresponding to the last 40 years, by weight and number, were obtained from the official fishery databases of the Servicio Nacional de Pesca de Chile (SERNAPESCA), Subsecretaría de Pesca del Gobierno de Chile, from FAO statistics, and from historical records of private and public institutions. Special attention was paid to the more complete records of 1978-1999. The annual distribution of cephalopod catches was analysed monthly.

Although there is information on the number of vessels, their specifications and fishing days for industrial fisheries, it is not possible to refer to fishing effort for cephalopods since the fisheries are multispecific. Moreover, cephalopods are a by-catch to the target species of fin-fish. Only the small-scale fisheries in northern Chile target O. mimus. However, the available databases lack detailed fishery statistics, catches or effort data regarding this octopus fishery.

Chilean territory is divided into 13 regions, 12 of which have coastal areas (Fig. 1). Cephalopod landing statistics for each of these 12 regions were obtained and analysed separately. The geographical distribution of catches and the importance of the different cephalopod fisheries were studied and evaluated. All data were transferred to and analysed with single PC-based spreadsheets (Microsoft Excel 2000).

\section{Results}

\subsection{Cephalopod catches}

Historical cephalopod catches mainly correspond to small-scale fisheries, followed by the industrialised fishing fleet (Table 1). There is no fishery dedicated solely to the 
capture of L. gahi and D. gigas in Chile and these two species are usually caught with trawls or gillnets as by-catch. Factory ships that fish in both national and international waters also take cephalopods, although their contribution is small. Cephalopods are occasionally caught as by-catch in fisheries dedicated to the capture of fish and for example in trawler fisheries for hake (Merluccius australis), Chilean nylon shrimp (Heterocarpus reedi) and red crab (Pleuroncodes monodon). The greater hooked squid Moroteuthis ingens is taken in Region XII (Fig. 1), but no official figures are available. O. mimus, however, is the target species of a dedicated small-scale fishery.

Historical records of cephalopod catches in Chile are sporadic and incomplete. Only in the last 20 years, there has been continuous monitoring of the three main species $-L$. gahi, D. gigas and O. mimus. Before 1978, all records of cephalopod catches refer to $D$. gigas. Given the minimal importance of these molluses in the national market, and the lack of official statistics and records, it is impossible to determine whether catches before 1978 actually were of $D$. gigas alone.

From 1978, landings of three species in Chile have increased. In 1978, some 69 tonnes were registered $(0.1 \%$ of the total mollusc catch), and in 1996 a total of 3503 tonnes was recorded (3.6\%). The largest annual capture occurred in 1992 with 15,169 tonnes $(11.3 \%)$.

\subsection{The Patagonian squid L. gahi}

L. gahi is fished mainly by small-scale and industrial fisheries (Table 1), mainly in the south of Chile (Regions VIII and X). Statistics of L. gahi landings are available since 1978 (Fig. 2). The main landing ports are Talcahuano and Tomé in Region VIII, and Puerto Montt, Calbuco and Castro in Region X. Sporadic catches are also made in Regions IV and V, where the largest landings of L. gahi were made in 1991 . The species is caught year-round, with maximum catches in summer and autumn and minimum captures during winter and spring. Catches varied between 20 and 500 tonnes.

\subsection{The jumbo flying squid D. gigas}


D. gigas is fished mainly by small-scale and industrial fisheries (Table 1). Records of landings of D. gigas are available since 1957. During the period 1991-1994, captures of

D. gigas were made year-round (with a minimum in spring) in Regions IV and V (Fig.

3). In the latter region, the main landings were recorded at San Antonio, followed by Quintero and Valparaíso.

Catches have been sporadic. For the period 1960-1972, a maximum of 3021 tonnes was taken in 1964. However, only 1-9 tonnes per year were recorded for 1973-1990.

Between 1991 and 1994, however, the annual catch rose to 9400 tonnes (1992), dropping once again after 1995 to between 1 and 8 tonnes per year (Fig. 3).

It is highly likely that since 1978, when records of L. gahi catches began, some landings recorded for L. gahi were in fact D. gigas and vice versa. L. gahi is superficially cognate to D. gigas juveniles and, therefore, the 302 tonnes captured by factory ships in international waters during 1995 registered as L. gahi (Table 1) may well correspond to D. gigas or another ommastrephid.

\subsection{The Changos octopus O. mimus}

The octopus fishery of northern Chile are made up of 2053 small-scale fishermen who free-dive for the species, taking specimens with gaffs. The fishermen work from 1209 boats of less than $15 \mathrm{~m}$ length. This fishery is concentrated in Regions I-III and the most important ports are Iquique, Tocopilla and Antofagasta.

Landings of O. mimus were first recorded in 1978 under the name Octopus vulgaris. Catches have increased since then, reaching 4877 tonnes in 1998. Fig. 4 shows the landing statistics 1987-1999. Landings occur year-round except between November 15 and March 15 when capture is forbidden.

\subsection{The octopus fishery in southern Chile}

The octopus fishery in southern Chile is comprised of small-scale free-diving fishermen, taking specimens with gaffs. After 1991, octopus catches were formally recorded in Regions VIII and X, with a maximum of 377 tonnes in Region X during 
1995 (Fig. 4). Although these landings were registered as O. mimus and are mixed with catches from the north of Chile, it is hard to be sure whether they really correspond to this species. Specimens from southern Chile examined by the present authors were identified as Enteroctopus megalocyathus, a species living in southern Chile and Argentina. At the present time, octopus catches in the south of Chile are approximately 200 tonnes per year.

\subsection{Commercialisation and exports}

Until 1996 more than $95 \%$ of the cephalopod catch was sold fresh or frozen with little processed and canned. The total production of frozen, fresh and canned cephalopod increased from 10 tonnes in 1978 to nearly 4000 tonnes in 1997, with a maximum of 10,629 tonnes in 1992 (Table 2).

Between 1991 and 1996, exports of frozen, fresh or canned cephalopods to a market of twenty countries oscillated between 2000 and 7000 tonnes per year, corresponding to $\$$ 5.2-\$17.1 million. The largest export tonnage since 1993 has been that of O. mimus. The main foreign markets for Chilean octopus between 1991 and 1993 were Spain (43\% in 1991 falling to $4.1 \%$ in 1993), the United States (4.3\% in 1991, rising to $53.4 \%$ in 1993) and Argentina (between 17 and 25\%). In 1998, octopus exports generated \$ 14.2 million, the main markets being Japan (64.8\% of frozen production and $35.0 \%$ of canned products), and Taiwan (23.6\% of frozen production and $60.6 \%$ of canned products).

\section{Discussion}

Chilean official cephalopod statistics have improved over recent years. Nevertheless other cephalopod species need to be taken into account, and species identification needs to be improved to avoid confusion and error in final numbers. Osorio (1989) cites five species of cephalopod exploited in Chile, of which Todarodes filippovae and Octopus fontanianus are not registered in official statistics. Other species, such as $M$. ingens, are not mentioned by Osorio (1989), even though their incidental captures are known in the southern Chile fisheries (Ojeda, personal communication). Several species of cephalopod, including deep-water octopods and sepioids, are captured in Chilean 
fisheries, especially trawl fisheries (Villaroel et al., 2001). Rocha (1997) listed 16 cephalopod species with fishery potential in Chilean waters, including L. gahi, D. gigas and O. mimus. Despite increased cephalopod landings and the present exploitation of captured species, they do not presently represent an important economic resource for Chile. There is, however, great potential for future development.

No information is available of the number of vessels involved in cephalopod fishing or their effort data, and therefore it is impossible to describe the fisheries in terms of overall cephalopod fishing efforts Most fisheries target fin-fish (except the octopus fishery) and are multispecific, with cephalopods taken as by-catch. The squid L. gahi may constitute a possible new resource for Chilean fisheries and could be developed in the southern area. For example, in Atlantic waters, a neritic species supports an important fishery on the Patagonian and Falkland Islands shelf. This international fishery is mainly concentrated in the south and east of the Falkland Islands Continental Zone (FICZ) where 35,000 tonnes of Patagonian squid were caught in 1999 (Hatfield and Des Clers, 1998; Falkland Islands Fisheries Department Web Page http://fis.com/falklandfish/). In Pacific waters, L. gahi is a commercially important species of small-scale Peruvian fisheries (Villegas, 2001). Under the scenario of a Chilean fishery focused on L. gahi, models of assessment and management would be required to minimise the risk of over-exploitation (Pierce and Guerra, 1994).

D. gigas is historically the most important species in Chilean waters (Rocha, 1997). Its abundance has experienced strong fluctuations (Wilhelm, 1951; FAO, 2000; SERNAPESCA database). This species is an important cephalopod resource in the eastern Pacific (Yamashiro et al., 1998; Nigmatullin et al., 2001). A commercial fishery based on D. gigas was established in Peru in 1991 by Japanese and Korean fleets. Peruvian fishery catches grew from 57,703 tonnes in 1991 to a maximum of 164,713 tonnes in 1994, later decreasing to a minimum in 1998 owing to the dispersion of stock in the face of environmental changes caused by the El Niño event of 1997-1998. At present, Peruvian Jumbo Flying Squid catches seem to be increasing due to new and favourable oceanographic conditions (Yamashiro et al., 1998; Josupeit, 2000; Taipe et al., 2001). The development of a seasonal Chilean fishery focused on D. gigas, such as currently exists in Peru, may be possible when abundance and oceanographic conditions permit. 
The O. mimus fishery in the northern Chile has been studied by Cortez (1995) and Defeo and Castilla (1998). These authors found that between 1991 and 1996, the catch per unit effort for the octopus fishery in Caleta Coloso, near Antofagasta (Fig. 1), ranged from 10.0 to $21.9 \mathrm{~kg} /$ sailing hour/diver. The Changos octopus is also caught in Peruvian waters by local fisheries with similar characteristics to their Chilean counterparts. Peruvian landings of octopods between 1989 and 1998 ranged from 270 tonnes in 1991 to 5123 tonnes in 1998 (FAO, 2000). As indicated by Guerra et al. (1999), the known distribution of O. mimus extends from northern Peru to San Vicente Bay (Region V) in Chile.

Main octopod captures in the south of Region VI have been identified as E. megalocyathus, an octopus known to live in southern Chile and Argentina. In southern Argentina, this octopod is captured by a small-scale fisheries (Ré, 1998). As in Chile and Peru, captures are by free-divers using gaffs. No official capture statistics for the species are kept in Argentina, although Ré (1998) estimates that catches in the Puerto Madryn area (Chubut, Argentina) fluctuate between 10 and 15 tonnes per year.

The octopus fisheries of both northern and southern Chile are regulated in the same way since their catches are considered to be of the same species. Correct identification and characterisation of the species are required in order that landings can be accurately regulated in southern Chile, and a proper evaluation made of its potential.

Apart from the three species discussed here, Chile has not considered other cephalopod resources despite the fact that this area of the Pacific and inhabiting species have potential to support their exploitation (Rocha, 1997; Caddy and Rodhouse, 1998). At present, 3.5 million tonnes of cephalopods are taken worldwide, of which the D. gigas catch in Peru and L. gahi and Illex argentinus in Argentina and the Falkland Islands represent a substantial proportion (FAO, 2000; Josupeit, 2000). The development of cephalopod fisheries is possible in Chile, but prospective campaigns need to be undertaken to locate the resources. Specific techniques would need to be adopted, such as fishing with jigs and lights, as well as investment in the fleet and the development of commercialisation strategies. Continuous monitoring would be essential, especially of cephalopod numbers and distribution with respect to oceanographic conditions, as 
would an increased understanding of the biology and ecology of the exploited species (Rodhouse, 2001; Anderson and Rodhouse, 2001).

\section{Acknowledgements}

We wish to thank Dr. Angel Guerra and Prof. Cecilia Osorio for valuable discussions and comments relating to the subject of this paper. Our thanks also to Adrian Burton and Ana Burton for preparation of the English text and Dr. Andy Dale for improving the final version. We would also like to thank the institutions and database sources used for this study.

\section{References}

Anderson, C.I.H., Rodhouse, P.G., 2001. Life cycles, oceanography and variability: ommastrephid squid in variable oceanographic environments. Fish. Res. 54, 133143.

Arancibia, H., Robotham, H., 1984. Crecimiento y edad del calamar (Loligo gahi Orbigny) de la Región Austral de Chile (Teuthoidea: Loliginidae). Inv. Pesq. (Chile) $31,71-79$.

Caddy, J.F., 1999. Fisheries management in the twenty-first century: will new paradigms apply? Rev. Fish Biol. Fish. 9, 1-43.

Caddy, J.F., Rodhouse, P.G., 1998. Cephalopod and groundfish landings: evidence for ecological change in global fisheries? Rev. Fish Biol. Fish. 8, 431-444.

Cortez, T., 1995. Biología y ecología del pulpo común Octopus mimus Gould, 1852

(Mollusca: Cephalopoda) en aguas litorales del norte de Chile. Ph.D. Thesis. Universidad de Vigo, España.

Defeo, O., Castilla, J.C., 1998. Harvesting and economic patterns in the artisanal Octopus mimus (Cephalopoda) fishery in a northern Chile cove. Fish. Res. 38, 121130.

FAO, 2000. FAO Yearbook. Fishery statistics, Capture Production for 1998, Vol. 86/1. FAO, Rome.

Guerra, A., Cortez, T., Rocha, F., 1999. Redescripción del pulpo de los Changos, Octopus mimus Gould, 1852, del litoral chileno-peruano (Mollusca: Cephalopoda). Iberus 17 (2), 37-57. 
Hatfield, E., Des Clers, S., 1998. Fisheries management and research for Loligo gahi in the Falkland Islands. CalCOFI Rep. 39, 81-91.

Josupeit, H., 2000. Los mercados mundiales de cefalópodos. Productos del Mar, Noviembre-Diciembre, pp. 43-48.

Kuroiwa, M., 1998. Exploration of the Jumbo Squid, Dosidicus gigas, resources in the southeastern Pacific Ocean with notes on the history of jigging surveys by the Japan Marine Fishery Resources Research Center. In: Okutani, T. (Ed.), Contributed Papers to International Symposium on Large Pelagic Squids, Japan Marine Fishery Resources Research Center, Tokyo, Japan, pp. 89-105.

Nigmatullin, Ch.M., Nesis, K.N., Arkhipkin, A.I., 2001. A review of the biology of the jumbo squid Dosidicus gigas (Cephalopoda: Ommastrephidae). Fish. Res. 54, 9-19.

Osorio, C., 1989. Las pesquerías de moluscos en el Pacífico sudeste. Rev. Pacífico Sur, Número Especial, pp. 529-541.

Pierce, G.J., Guerra, A., 1994. Stock assessment methods used for cephalopod fisheries. Fish. Res. 21, 255-285.

Ré, M.E., 1998. Pesquerías de pulpos. In: Boschi, E.E. (Ed.), El mar Argentino y sus Recursos Pesqueros. Tomo 2. Los Moluscos de Interés Pesquero. Cultivos y Estrategias Reproductivas de Bivalvos y Equinoideos. Instituto Nacional de Investigación y Desarrollo Pesquero, Mar del Plata, Argentina, pp. 99-114.

Rocha, F., 1997. Cephalopods in Chilean waters: a review. Malacol. Rev. 30, 101-113.

Rodhouse, P.G., 2001. Managing and forecasting squid fisheries in variable environments. Fish. Res. 54, 3-8.

Taipe, A., Yamashiro, C., Mariategui, L., Rojas, P., Roque, C., 2001. Distribution and concentrations of jumbo flying squid (Dosidicus gigas) off the Peruvian coast between 1991 and 1999. Fish. Res. 5, 21-23.

Villaroel, J.C., Vega, M.A., Acuña, E., 2001. Cefalópodos recolectados en la pesquería de crustáceos de la zona norte y centro-sur de Chile. Rev. Biol. Mar. Ocean. 36 (1), 83-97.

Villegas, P., 2001. Growth, life cycle and fishery biology of Loligo gahi (d'Orbigny, 1835) off the Peruvian coast. Fish. Res. 54, 123-131.

Wilhelm, G.O., 1951. Algunas observaciones acerca de las mortandades de jibias (Dosidicus gigas D’Orb.), en el litoral de Concepción. Rev. Biol. Mar. 4, 196-201. 
Yamashiro, C., Mariátegui, L., Rubio, J., Argüelles, J., Tafur, R., Taipe, A., Rabi, M., 1998. Jumbo flying squid fishery in Peru. In: Okutani, T. (Ed.), Large Pelagic

Squids. Japan Marine Fishery Resources Research Center, Tokyo, pp. 119-125.

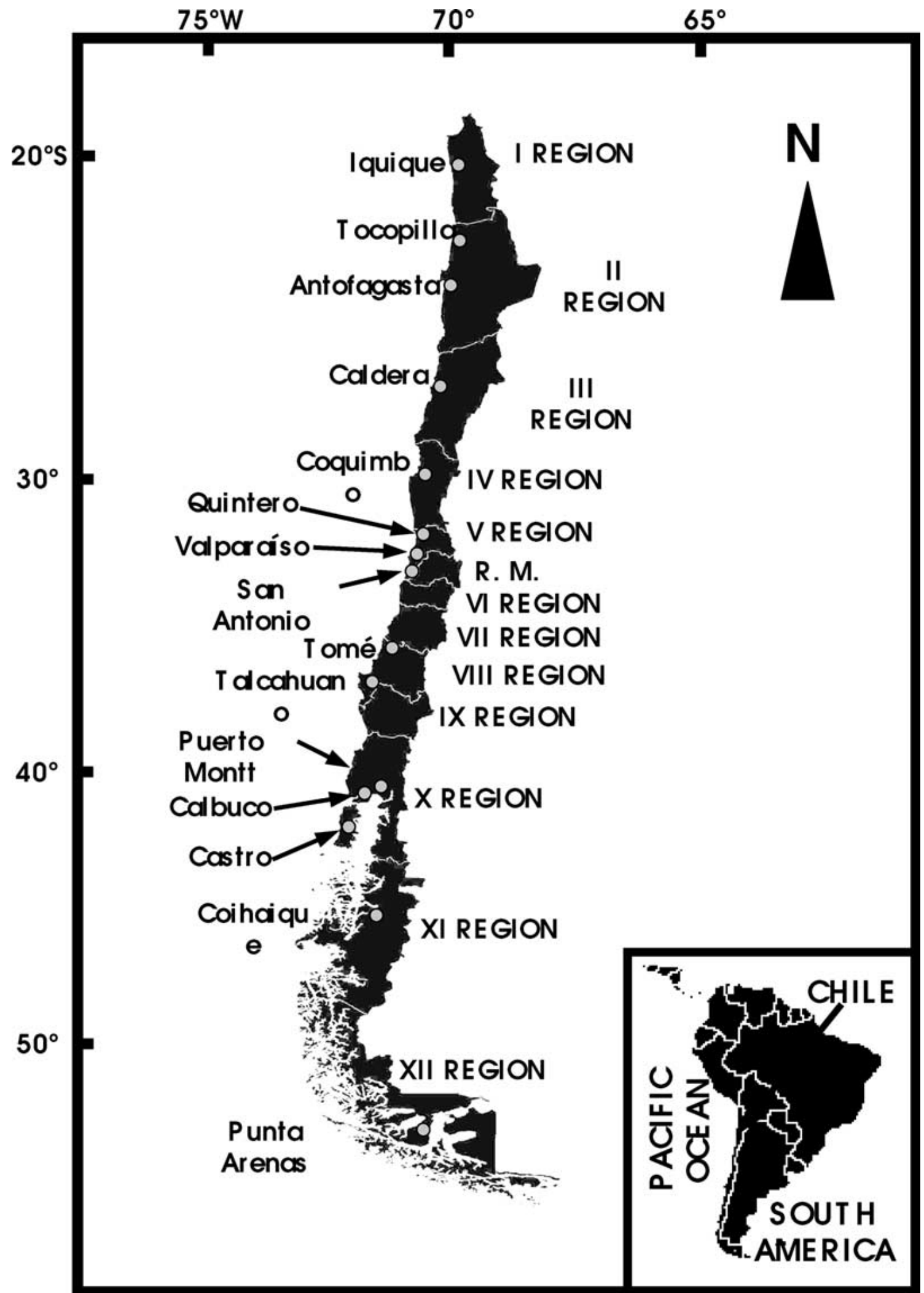


Fig. 1. Map of Chile showing the main ports and political divisions. R.M.: Región Metropolitana.
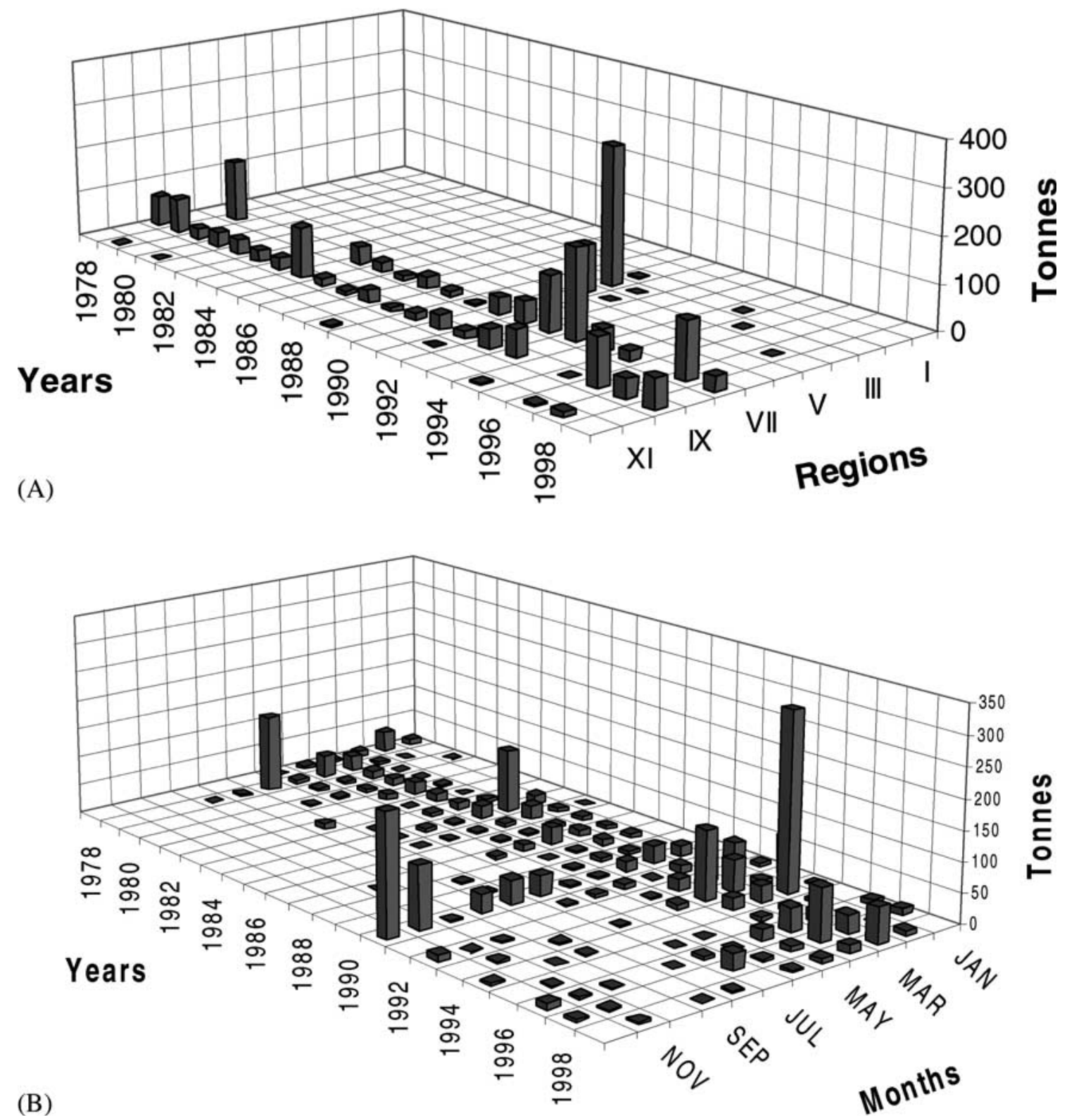

(B)

Fig. 2. Distribution of regional (A) and monthly (B) landings of L. gahi in Chile from 1978 to 1999. Data from SERNAPESCA (Chile), Subsecretaría de Pesca del Gobierno de Chile and FAO statistics 

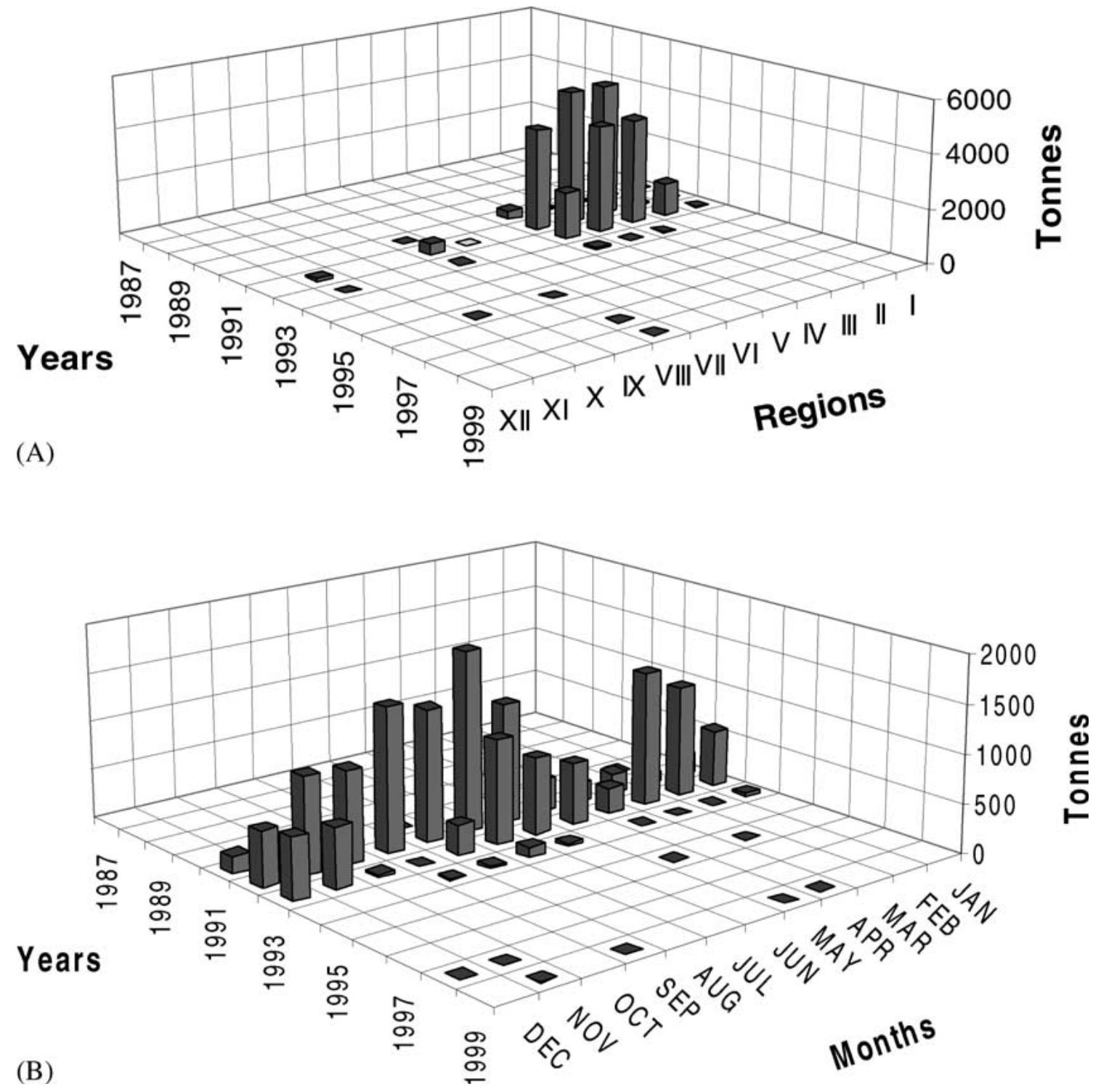

Fig. 3. Distribution of regional (A) and monthly (B) landings of D. gigas in Chile from 1978 to 1999. Data from SERNAPESCA (Chile), Subsecretaría de Pesca del Gobierno de Chile and FAO statistics 

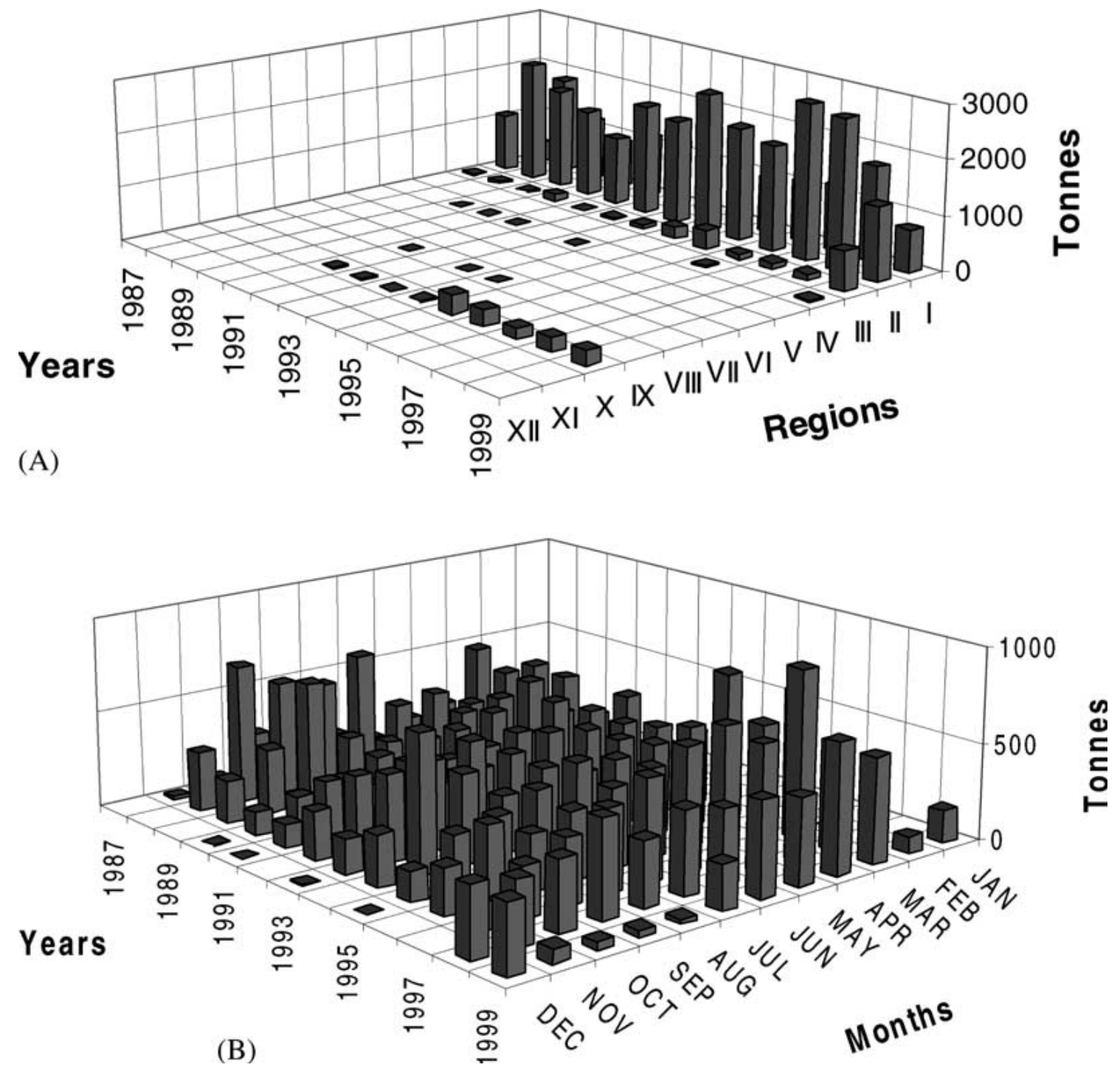

Fig. 4. Distribution of regional (A) and monthly (B) landings of Octopus spp. in Chile from 1978 to 1999. Data from SERNAPESCA (Chile), Subsecretaría de Pesca del Gobierno de Chile and FAO statistics.

Table 1. Cephalopod landings in Chile from 1987 to $1999^{\mathrm{a}}$

Fishery 1987198819891990199119921993199419951996199719981999

L. gahi

$\begin{array}{llllllllllllll}\mathrm{SSF}^{\underline{b}} & 18 & 54 & 26 & 20 & 72 & 66 & 162 & 256 & 52 & 24 & 110 & 174 & 91\end{array}$

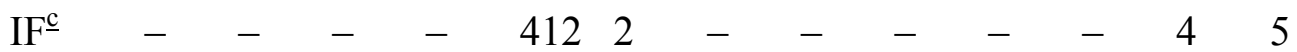

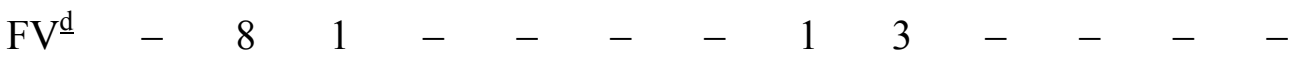

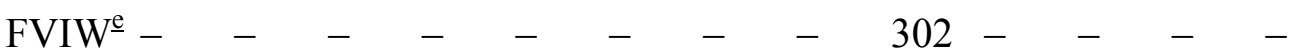

D. gigas

SSF $\quad-\quad-\quad-\quad-4428240689543-4 \quad 2 \quad-\quad-\quad-$

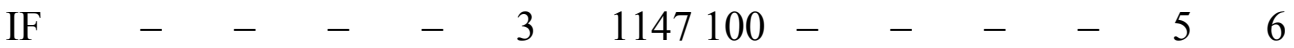




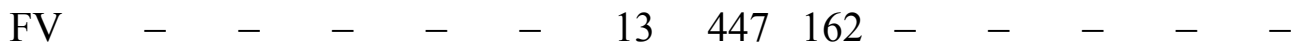

FVIW -

O. mimus

SSF 1526415730752646242532863599373137963477440448773168

IF $\quad-\quad-\quad-\quad \begin{array}{llllllllllllll} & 6 & 13 & - & 9 & 1 & - & - & - & - & -\end{array}$

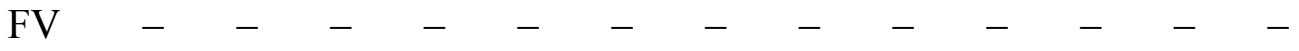

FVIW -

${ }^{a}$ Landings in tonnes. Data from SERNAPESCA, Chile.

${ }^{\mathrm{b}}$ Small-scale fishery landings.

${ }^{\mathrm{c}}$ Industrial fishery landings.

${ }^{\mathrm{d}}$ Factory vessel landings.

${ }^{\mathrm{e}}$ Factory vessel landings from international waters.

Table 2. Cephalopod production in Chile, 1978-1999a

\begin{tabular}{|c|c|c|c|c|c|c|c|c|}
\hline L.. & & & D. gic & gas & & O. $m$ & imus & \\
\hline Fre & Froze & Can & Fresh & Froze & Can & Fres & Frozer & Canned \\
\hline 1978 & & 10 & & & & & & \\
\hline 1979 & 46 & 23 & & & & & 1 & \\
\hline 1980 & 9 & 5 & & & & & & \\
\hline 1981 & 8 & 5 & & & & & & \\
\hline 1982 & 14 & & & & & & 40 & \\
\hline 1983 & 138 & & & & & & 914 & \\
\hline 1984 & 177 & & & & & & 1173 & \\
\hline 19851 & 32 & 6 & & & & & 1009 & \\
\hline 1986 & 11 & 4 & & & & 88 & 2008 & \\
\hline 1987 & 14 & 2 & & & & & 1219 & 3 \\
\hline 1988 & 27 & 10 & & & & & 3546 & 12 \\
\hline 1989 & 6 & 3 & & & & & 2660 & 2 \\
\hline 1990 & 4 & 6 & & & & & 2286 & \\
\hline 1991 & 3811 & 17 & & 113 & 3 & 4 & 2051 & \\
\hline 19922 & 52 & & 1204 & 4049 & 72 & 4 & 2801 & 30 \\
\hline 1993 & 147 & 16 & 1461 & 3023 & 85 & 5 & 3143 & 26 \\
\hline 1994 & 216 & 28 & & 159 & 40 & 166 & 3182 & 3 \\
\hline 1995 & 722 & 5 & & & & 49 & 3256 & 3 \\
\hline 1996 & 137 & 29 & & 1 & & 108 & 2932 & 2 \\
\hline 1997 & 88 & 25 & & & & 90 & 3729 & 4 \\
\hline 199818 & 122 & 20 & 6 & & & 86 & 4573 & 17 \\
\hline 199916 & 69 & 5 & 3 & & & 24 & 3000 & 12 \\
\hline
\end{tabular}


a Production in tonnes. Data from SERNAPESCA, Chile 